\title{
JOHN RIDLEY STROOP: CREATOR OF A LANDMARK COGNITIVE TASK
}

\author{
COLIN M. MACLEOD \\ University of Toronto, Scarborough Campus
}

\begin{abstract}
The Stroop colour-word task, the most widely used demonstration of interference in attention, has provided a fascinating empirical and theoretical puzzle for cognitive psychologists for over half a century. This historical note provides a biographical sketch of the task's creator, John Ridley Stroop, and examines the impact of his task on cognitive psychology.
\end{abstract}

For over half a century, one of the standard demonstrations in undergraduate psychology courses and laboratories has been the Stroop effect. When asked to name the colour of ink in which an incompatible colour word is printed (e.g., to say "red" aloud in response to the stimulus word GREEN printed in red ink), people take longer than to name the same ink color in a suitable control condition (e.g., to say "red" to the stimulus XXXXX printed in red ink). The effect is a large and highly replicable one, almost always evoking frustrated laughter from those performing the task for the first time. The effect is made more interesting by the fact that, when asked to read the word in the incongruent condition (e.g., saying "green" to the word GREEN printed in red ink), there is virtually no decrement relative to the usual control (i.e., saying "green" to the word GREEN printed in standard black ink). To a large extent, it is the magnitude of the effect and its asymmetry that has intrigued investigators up to the present.

This phenomenon was first reported in the lead article of the December, 1935 issue of the Journal of Experimental Psychology by John Ridley Stroop (Stroop, 1935a). Since that time,

I am most grateful to Mrs. Zelma Stroop and to Mr. Fred Stroop for kindly providing me with much of the information upon which this article is based. Additional information was drawn from Stroop's obituary, written by his friend and colleague, Lewis Maiden (1973). Preparation of the manuscript was supported by Natural Sciences and Engineering Research Council of Canada grant A7459. I thank Kevin Dunbar, Bert Forrin, and Michael Masson for their helpful comments on an earlier version of this article. Correspondence should be addressed to Colin M. MacLeod, Division of Life Sciences, University of Toronto, Scarborough Campus, Scarborough, Ontario, CANADA MIC 1A4. Electronic mail should be addressed to macleod@lake.scar. utoronto.ca.

over 700 studies of the Stroop effect have been published, each attempting to explore this robust result in some new way. I have surveyed this large literature elsewhere (MacLeod, 1991). The present article is a companion piece to that review, a historical note on the man behind one of the most widely known tasks in cognitive psychology. Who was he and how did he come to develop this benchmark task?

\section{A Biography of John Ridley Stroop}

John Ridley Stroop was born March 21, 1897 in a small farming community called Hall's Hill, in Rutherford County, seven miles outside Murfreesboro, Tennessee. He was the second youngest of six children; he had two sisters and three brothers. His middle name - the name his family called him and the one which he would use in his publications - was chosen in recognition of a preacher in the community whom his parents admired. As an infant, Stroop was not expected to live, which led his parents to shelter him during his childhood. Unlike the other family members, he was not required to do heavy physical work on the family farm.

Stroop's initial schooling was at Kitrell County School, where he graduated at the top of his class. His later education and his years as an educator all centred around David Lipscomb College in Nashville. Founded by David Lipscomb and James Harding and originally called the Nashville Bible School, the college was renamed in 1918, a year after Lipscomb's death. Stroop graduated from David Lipscomb High School in 1919 and obtained a diploma from David Lipscomb Junior College in 1921, serving as valedictorian. His initial financial support was a small amount of money his father obtained from selling two cows and a horse. Stroop also helped to finance himself

Canadian Psychology/Psychologie canadienne, 1991, 32:3 


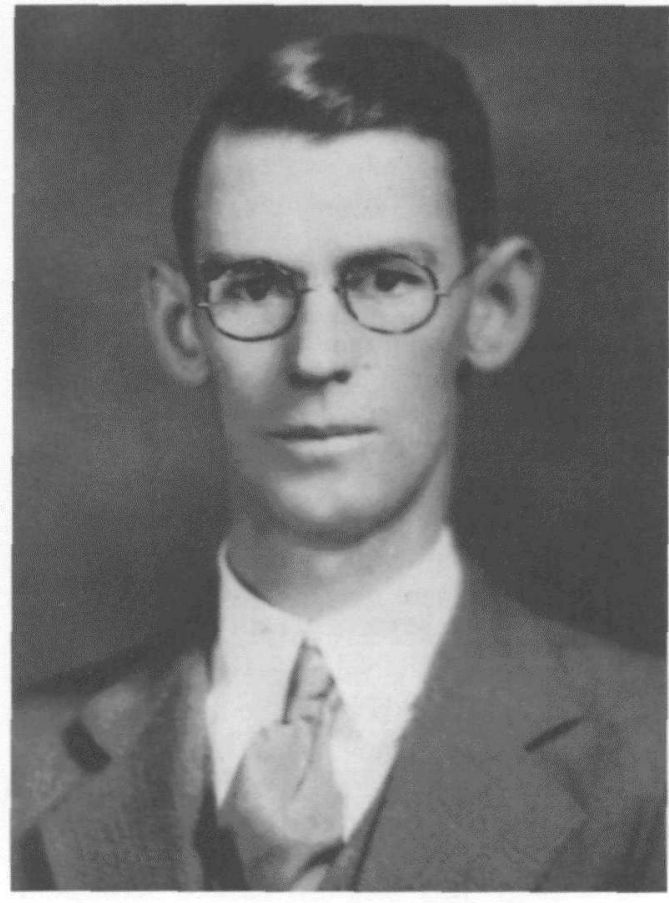

Figure 1. John Ridley Stroop around the time of his dissertation at George Peabody College, circa 1933.

by growing and selling a crop of potatoes the summer before college.

On December 23, 1921, during his second year in college, Stroop married Zelma Dunn, great niece of Margaret Zellner, Mrs. David Lipscomb. Over the next seven years, while he was in university, they had three sons. To support his growing family, Stroop continued to teach at David Lipscomb College during his university years. He also worked as a janitor and as a librarian and taught high school, in addition to building his own house during that time.

Stroop's university education also took place in Nashville, at George Peabody College. There, he earned a B.S. in 1924, an M.A. in 1925, and the Ph.D. in Experimental Psychology, with a minor in Educational Psychology and an elective in Education, in 1933. Stroop had begun teaching well in advance of obtaining his doctoral degree. He had been principal at a Mississippi Consolidated School in 1921-1922 before returning to David Lipscomb College to begin a teaching career which, with only a couple of interruptions, spanned over 40 years. He began there as an instructor in Mathematics and English (19221923), then switched to Modern Languages (1924-1928). Between 1928 and 1932, he was
Professor of Psychology and Education, serving as Dean of the Faculty for the 1928-1929 academic year.

After obtaining his Ph.D., Stroop conducted research for the Tennessee Educational Commission (1933-1934), then served briefly as a special instructor in Psychology and Education at Tennessee Polytechnic Institute in Cookeville, Tennessee. A curriculum vitae circa 1935 lists his membership in the American Psychological Association and the Southern Society of Psychology and Philosophy, as well as his recognition in American Men of Science and Who's Who in America.

Upon returning to David Lipscomb College to stay, he served the college in many capacities, including Registrar for 11 years and Chair of the Psychology Department for 16 years, from 1948 to 1964. At David Lipscomb, Doctor Stroop (or Brother Stroop, as he was also called) was known as an intelligent, good man of deep religious conviction. He was an individualist who treated everyone as his equal. As a teacher, he was tough but fair, considered one of the very best at the college. He was especially noted for his dry sense of humour and fondness for puns.

Stroop retired in 1967, and spent 1967-1968 as Dean of Ohio Valley College in Parkersburg, Virginia, after which he took up the position of Emeritus Professor of Biblical Studies at David Lipscomb College (now University) until his death on September 1, 1973 at the age of 76.

The greatest force in Stroop's life was his religion. Baptised into the Church of Christ in 1913, he was a devout Christian for his entire life. From his college days on, he preached every Sunday, often taking a train out into the country and being paid with a chicken or a bag of potatoes, if at all. He always kept a card file indicating for each Sunday where he had spoken and what his topic had been. He also taught Bible classes throughout his years at David Lipscomb College, including a popular early morning class on how to live life according to the Bible.

Out of Stroop's biblical teaching emerged seven books, including his major work, the trilogy God's Plan and Me. As Maiden (1973, p. 682) says of Stroop's books, "They are widely used as texts in Christian schools, in Bible classes, in congregations, and in teacher training classes." The Bible, not psychology, was his life's work. Still, his dissertation has had a continuing influence in psychology, and it is to this influence that I turn now. 


\section{The Impact of J. Ridley Stroop's Research}

The task Stroop created was not a wholly novel one. Rather, his creative contribution was in synthesizing ideas and procedures already in the psychological literature that stretched back to the very beginnings of experimental psychology fifty years earlier. The work descended from a noble lineage. James McKeen Cattell (1886), at the instigation of his doctoral supervisor, Wilhelm Wundt, had undertaken to explore the time it took people to name objects and the properties of those objects, as well as to read the corresponding words. He reported a stable finding: Reading the words took less time than naming the objects or properties, the latter including colour. Although a recurring subject of study over the next half century, it was not until Stroop's article that anyone thought to combine the word and object/property dimensions in the same stimulus, creating the now famous situation of response conflict. ${ }^{\prime}$

Stroop's dissertation research was carried out in the Jesup Psychological Laboratory under the supervision of Professor Joseph Peterson, who was clearly influential in Stroop's choice of a dissertation topic (see the footnote and introduction to Stroop, 1935a). The classic 1935 paper is his dissertation. To my knowledge, he published only three other articles in experimental psychology, all in the period 1932-1938. The first was on group as opposed to individual judgments (Stroop, 1932). Together with his dissertation, there were two other papers on the color-word issue, one a critique of an extant theory (Stroop, $1935 \mathrm{~b}$ ), the other a test of a possible explanation of the Stroop effect (Stroop, 1938), in part as a tribute to Peterson, who had died in 1935.

Stroop's dissertation has had a profound and lasting effect on cognitive psychology. The task is widely used to index attentional and linguistic processes, as detailed in my review (MacLeod, 1991). In addition, the challenge of understanding the Stroop effect links directly to two of the most influential explanatory ideas in the field. These ideas - (1) that certain processes, such as the reading of words, are automatic and

\footnotetext{
IJensen and Rohwer (1966) point out that Jaensch (1929) had integrated the two dimensions - word and colour - a few years before Stroop, but Jaensch's work has received scant attention relative to Stroop's. The exceptional experimental rigor of Stroop's work, together with its empirical and conceptual clarity, no doubt have contributed to the identification of the idea with Stroop's article.
}

hence obligatory, and (2) that certain processes are carried out faster than others and hence have implications for slower processes - have both been used to illuminate inhibitory effects in processing. The Stroop effect has often been cited as a hallmark illustration of both ideas, although the reviewed literature suggests that neither position is completely correct.

Stroop's dissertation can be seen as the culmination of work early in this century aimed at understanding response time as a window on mental processes. Yet, at the time of its publication, it had relatively little impact, probably because it was published at the height of Behaviorism in America. It is only since the 1960 s, with the advent of information processing as the dominant perspective in cognitive psychology, that Stroop's work has been rediscovered. The Stroop effect has been one of the primary results used to highlight the goal of examining stages of mental processing through the analysis of response time.

Another reason why Stroop's work may not have had more impact at the time of its publication is that he himself did not continue working on the topic. He saw his religion - not psychology - as his life's mission. As his wife wrote in her biographical sketch of him:

\footnotetext{
"His major professor at Peabody, Dr. Joseph Peterson, invited him to collaborate with him on a research project furthering the study of [Stroop] 's doctorate thesis. Dr. Peterson's unexpected death prevented such from happening. This was probably the changing of his work as he became more involved in teaching the Bible and writing in that field."
}

Although aware of the impact of his work in psychology, thirty years after his landmark paper Stroop himself claimed to have no interest in the task he had created (Jensen \& Rohwer, 1966). As his son Fred put it when I spoke with him, his father's psychological research was "insignificant to his Bible-oriented life and teaching".

There are few phenomena in psychology so robust that they appear in virtually every introductory text and are known by researchers in almost every subarea of the discipline. The Stroop effect is one of these rare phenomena. Understanding the Stroop effect may ultimately lead us to a fuller comprehension of how attention works and of the place of attention in a more general theory of cognition. Research on the Stroop effect continues today and shows no signs 
of abating; indeed, it seems to be on the increase. John Ridley Stroop was a pioneer, instrumental in providing one of the tools most valued by cognitive psychologists. A half century later, the task that bears his name continues to be a challenging puzzle for experimental psychologists to solve.

\section{Résumé}

La tâche couleur-mot de Stroop, la démonstration de l'interférence d'attention à laquelle on a le plus souvent recours, constitue un énigme à la fois théorique et empirique qui fascine les psychologues cognitifs depuis plus d'un demi-siècle. Cette note historique présente un esquisse biographique du créateur de cette tâche, John Ridley Stroop, et examine l'impact de sa tâche sur la psychologie cognitive.

\section{References}

Cattell, J.M. (1886). The time it takes to see and name objects. Mind, $11,63-65$.

Jaensch, E.R. (1929). Grundformen menschlichen Seins. Berlin: Otto Elsner.

Jensen, A.R., \& Rohwer, W.D., Jr. (1966). The Stroop color-word test: A review. Acta Psychologica, 24, 398-408.

MacLeod, C.M. (1991). Half a century of research on the Stroop effect: An integrative review. Psychological Bulletin, 109, 163-203.

Maiden, L. (1973). Obituary: J. Ridley Stroop. Gospel Advocate, October 25, 1973, 682-683.
Stroop, J.R. (1932). Is the judgment of the group better than that of the average member of the group? Journal of Experimental Psychology, 15, 550-562.

Stroop, J.R. (1935a). Studies of interference in serial verbal reactions. Journal of Experimental Psychology, 18, 643-662.

Stroop, J.R. (1935b). The basis of Ligon's theory. American Journal of Psychology, 47, 499-504.

Stroop, J.R. (1938). Factors affecting speed in serial verbal reactions. Psychological Monographs, 50, 38-48.

Accepted for publication / January /99I 